\title{
Physical Geography in High Schools
}

\section{Mary I. Platt}

To cite this article: Mary I. Platt (1904) Physical Geography in High Schools, Journal of Geography, 3:8, 379-386, DOI: 10.1080/00221340408985535

To link to this article: http://dx.doi.org/10.1080/00221340408985535

$$
\text { Published online: } 12 \text { May } 2008 .
$$

5 Submit your article to this journal $\square$

Џ Article views: 5

Q View related articles $\sqsubset$ 
7. The systematic study of pictures is a profitable form of geographical work.

8. Relief models and contoured maps are better adapted to secondary and collegiate students than to elementary students.

9. The study of specimens of any kind is most satisfactory when the pupils collect the specimens which they study.

10. Field trips, whenever possible, are the most valuable form of all practical work in geography.

\title{
PHYSICAL GEOGRAPHY IN HIGH SCHOOLS*
}

\author{
BY MARY I. PLATT \\ High School, Brookline, Mass.
}

P

HYSICAL geography, though in one sense as old as the hills themselves, has been looked upon and is still considered a comparatively new subject. It has a brief past, a period which was not formative and preparatory, but which rather represented a cycle of inactivity preceding renewed activity or revival. Its present we are in the midst of - a period also brief-characterized by activity and accomplishment such as should be characteristic of the youth of any life-characterized also undoubtedly by some of the mistakes which necessarily accompany experiment. Toward its future we are now looking forward, to be characterized, we hope, by increased activity and accomplishment, by steadiness and stability also. It is my purpose in the following paper to give very briefly an account of the past, the present, and of what we hope for in the future of physical geography in the high schools of our country. Twenty years ago physical geography was a subject which appeared in the curriculum of public and private schools as one to be pursued for a term of from sixteen to twenty weeks if so elected by the pupils themselves. These pupils had passed through the preliminary steps of political geography in the grammar schools, where the emphasis had probably been laid upon arbitrary memory efforts in the study of political and natural features, and now found themselves confronted with new and more difficult problems in their high-school geography.

To the standard text-book of that time (Guyot's) the modern physical geography owes much, and to it also, I believe, many of the more mature students and teachers of physical geography trace their first

\footnotetext{
* Presented before the Educational Section of the Eighth International Geographic Congress.
} 
interest in the subject and their first inspiration along such lines. Concise, interesting, vivid, giving cause and effect their due share in the treatment of the successive problems of physical geography, those of us who studied or taught it still find its very language coming often to our lips, making a ready tool for rapid work. Other books most frequently used two decades ago were Warren's and Maury's. These books were all similar in style-in outer form the type geography of our childhood; within, the subject-matter was arranged in double columns of alternating coarse and fine print, with no attempt at illustration. They were much less attractive to the eye than our newer books. The problems which, when strictly classified, we designate as meteorological were less empirical than those of physical geography proper. Here, however, explanation was not omitted-on the contrary, much more difficult explanations were given than are now attempted. It was not upon the text-books, then, that the burden of responsibility for the unsatisfactory condition of the subject in schools rested. This was divided between the school authorities, who gave the subject no consideration, and the teacher, who, chosen for convenience sake, was often wholly unfitted for the work.

As a result of this low standing of the subject, and the low standards set for the teacher, the presentation naturally lacked much that we now consider essential. The method was purely a text-book method. Each topic was presented as a complete unit-a chapter to be opened, committed, and finished with little reference to the preceding or to the future topics; cause and consequence were but little dwelt upon, and the laboratory method was practically unheard of. Notwithstanding the adverse conditions under which it labored, physical geography was considered an interesting study from the very character of the subject-matter. The whole thing lacked vitality-lacked reality. It was presented as a series of spectacles, the most sensational being most emphasized and longest remembered. Too much emphasis was laid upon externals - too little upon structure, process, and gradual change, the idea of the impermanence of the everlasting hills was scarcely grasped, and the classification of land forms according to their phase of development was not attempted. Systematic botany and zoölogy were at their zenith, but classification in geography was almost purely arbitrary and based upon externals. Only great teachers recognized any other. Outdoor observations were purely accidental or incidental at the best, and there was only the most casual connection between the actual outdoors and the mountains and hills, the rivers and valleys 
of the book. Definitions were much insisted upon, and partook of the general empirical character of the teaching; they were most arbitrary and quite satisfactory if one could accept them.

The aim of the teaching of physical geography was a somewhat shifting one, in keeping with its transitory position in the course. It could hardly have been called a culture subject, nor was it as disciplinary as some of the other sciences of the schools. It was too often a stop-gap or a makeshift, and its results tallied closely with the skill and effort put into the work of preparation and teaching.

During the last fifteen years, or perhaps, more accurately speaking, during the last ten years, physical geography has made great progress. First, in popularity -it is now taught in nearly all good city schools, and appears on the curriculum in many of the smaller schools of New England and New York, while the Central West is undoubtedly more progressive in this respect than is the East. Its popularity among pupils has increased also with its wider field and with the improved methods and facilities for teaching. Its appeal to pupils, whether of mature or immature minds, is unquestioned.

Its position in the school course is a varying one, but it is a much more secure one than formerly. Ordinarily it is offered as an elective, in some schools to the first-year pupils, in others to those of the second year, while in others it is taught as a more advanced subject to the juniors and seniors, or again it may be given early in the course and then reviewed and enlarged upon later in preparation for college. There is something to be said in favor of each of these methods, even from a disinterested standpoint, and in view of the needs and requirements of each individual school there is much to be said as a reason for putting it either in the first, second, or third years. In a year's study of physical geography, whether it be early or late in the course, we find it practicable to study type land-forms, to describe them, follow their history, classify them, learn something of their human value, and finally to apply the type to other lands. We study briefly the ocean with its main features and motions, and lastly the atmosphere and its phenomena. This study is, of course, all elementary, and yet the results attained compare very favorably with those in more advanced classes-they are encouraging and very real. It enables the pupils to interpret what they have already seen; it opens their eyes and their minds to much that they have never seen; it arouses a questioning attitude and a new alertness; it makes travel doubly interesting and it is not easily forgotten. I have put elementary 
meteorology last in order as I do in teaching, but it is by no means last in importance or interest, and should be included in every course in physical geography, no matter how elementary.

Within the last ten years, also,'new text-books have been published which mark a new epoch in the teaching of physical geography. Put forth by men of acknowledged attainments and leadership, the best ones among them bear the hall mark of authority. Attractive in form, scientific and accurate, and increasingly practical, our presentday text-book in physical geography marks the most rapid advance in value and the quality of teachableness. The very nomenclature of the modern text-book is in itself an indication of the difference between the new and the old in physical geography. Doctor Crothers has said in a recent essay that a noun is known by the adjectives it keeps, and this is quite as true in physical geography as in literature. A young river or a drowned river, a young or a subdued mountain, at once conveys a picture to the present-day student of physical geography. But a few years ago such nouns did not keep company with such adjectives, and the terms would have been quite unintelligible even to students of the subject. Cuesta and Peneplain are new nouns which convey their own meaning without associating adjectives. Progress has been made also in supplementary material to which pupils may be sent as to original sources. This is in the form of monographs on geographical subjects and state and town geographies or geologies, all of them too few in number, considering their excellence.

Under the guidance of some of the more recent of our best text-books physical geography must be taught as a laboratory subject, and is at once taken out of the realm of the abstract and the empirical. Laboratory work and laboratory equipment have made less rapid advance than text-books, and along this line there is the most inviting field for progressive work. Field work as a branch of laboratory work also offers most promising opportunities for the activity of original minds.

In the presentation of a subject which has the status of physical geography in the high schools of to-day the teacher is a most important element; this is undoubtedly true always, but less strikingly so in subjects where lines of work are already very definitely laid out. The work of physical geography demands a teacher technically trained, progressive, judicious in experiment, enthusiastic, and open-minded. With the emphasis now laid upon professional training, the increasing demand for technical preparation, and the increased opportunities for preparation along special lines, the number of teachers especially 
prepared for this subject is increasing, and with this improvement in the teaching force the quality of work done has also improved. In the more advanced schools, a college course, years of special study on the subject, or summer study at home or abroad, now fit the teacher of physical geography.

Both the impulse toward better work on the part of the teacher and the opportunities for doing better work have come from above rather than below. Because to our leading colleges, and oftentimes to single individuals in those colleges, do we owe both inspiration and opportunity. Harvard, Cornell, Chicago, and Columbia, and an increasing number of other colleges, now give courses in geography which are most valuable to teachers and advanced students, while the summer schools offer opportunities for brief but intensive work to the larger number who cannot avail themselves of the full college courses. To college professors also we owe our text-books, and, in large measure, our present tendency toward laboratory work.

If in all or most of our high schools these things were true; that there was laboratory equipment for physical geography; that it occupied an acknowledged place in the school course; that abundant time was given to it; that the text-book was scientific and satisfactory, and the whole subject in the hands of a competent teacher, then we might say that physical geography had indeed made great strides. These things are true in many schools, and increasingly true each year, but the fact remains that there are also many schools - some of them among the largest and best equipped-where methods of teaching prevail which are more representative of the past than of the present-a condition of things which is the result of the plan of school administration. In such schools insufficient time is given to the subject; it is frequently introduced in the school course to serve a temporary exigency; no trained teacher is provided, and in some cases no text-book. This, however, is not a permanent condition-it simply means that the whole subject is in a transitional stage. A lecture course in a high school or a brief course based wholly on the book is merely a beginning, which must soon of necessity lead to better things. The conditions now are very hopeful, and I feel almost inclined to say that those who shape the work in physical geography at the present day hold the schools in the hollow of their hands. College preparatory high schools, where the traditions are most strongly classical, have introduced and are introducing physical geography as a subject opening a comparatively new and hopeful field. Schools which offer a 
general course for the sake of numbers of pupils, who finish their school career with the high school, have introduced it or are ready to do so, as a practical subject suited to the needs of many pupils. Schools which attempt to do both these things must of necessity make it a part of their work and the manual training schools also. There is a very wholesome attitude of mind among people in general toward outdoor subjects, an attitude, too, which demands a certain vitality in our treatment of outdoor things, a breadth, and strength, and largeness such as can well be used when one studies the big things of nature.

The course of the high school itself is in a somewhat unsettled stage; old traditions are giving way and much that is new is being added. The work in the New Geography, so called, has been notable for its individuality, if I may so term it; one man in a college here and there has sent out teachers who, acting in the inspiration thus received, have carried the work to widely separated schools. This work has been individual not only in the sense of large dependence upon one personality, but both methods and results have been stamped with individuality.

This period has had the advantage of independence and opportunity and so it will continue to have. Until very recently no effort has been made to unify the subject work in any way. Valuable suggestions leading to greater uniformity of treatment have been made by the Committee of Ten. The outlines prepared by the National Educational Association and by the College Examination Board have also been steps toward a certain uniformity, and in New England informal conferences, participated in by teachers of geography and geology, have looked toward the same end. This individualistic phase through which we are passing is about to give way to a period of greater unity. We have been working toward the same ends, but we have pursued diverse means. By experiment, comparison, and elimination we have established certain principles of work, even in the laboratory and field work where the greatest divergence has existed. From our various experiences I think we may safely be said to agree on a few simple fundamental principles. Among others, that the subject should be largely a laboratory subject; that the laboratory work should consist partly of outdoor work, the character of the latter to be largely controlled by the natural features of the locality; that the time given to it should equal if not exceed that given to text-book work; that it should follow the order of subjects as given in recitations and should precede the recitation if possible. Our work should proceed from the general 
to the specific, aiming to cultivate power of inference, independence in thought, practical observation, and the ability to visualize from type forms. It should acquaint the pupil by means of description, map, or model with a large number of type forms, which he will at the end be able to classify and extend to a wider application. Both textbook work and the laboratory work should be most definitely laid out in order to obtain the best results when dealing with the immature minds of our high-school children.

Some believe that the text-book of physical geography is still to be written, and as this is undoubtedly true of all subjects in the school curriculum, it must needs be true in so new a field as the new geography. The great need of the immediate future is a laboratory book which shall follow quite definitely the order of work in our best textbooks. Such a book would be of the greatest help in systematizing the subject and also in giving courage to teachers who have not had special training, and who dread to initiate work with which they are themselves unfamiliar. A beginning has been made and the need will soon be met by a satisfactory book of suggestion and outline. I hope the time will never come when forty exercises in physical geography shall be laid down as a necessity for the secondary schools sending pupils to college, for from the very nature of our laboratory work and material no arbitrary outlines can be followed in detail. Outdoor observations on the Atlantic coastal plain must of necessity differ from corresponding work in the old land of New England or the delta of the Mississippi. Among our immediate needs, also, I would place additional monographs on geographical subjects, and an increasing number of state and town geographies, all of them up to the standard of those at present published.

The position of physical geography in the school curriculum must be a surer one, though not necessarily an unchangeable one, that can only be dictated by the needs of the individual school. More time also is needed for its proper development. In schools which give the most attention to the subject a year is now allowed for it, and this is well; but if an opportunity could be given to large numbers of the entering class in high schools to study physical geography in an elementary way, and then this could be followed by a half year of advanced study later in the course. it would be better. In the crowded condition of the high-school course I doubt if this would be practicable in many schools. The value of physical geography being proved both as an informational and disciplinary subject, our experts in school 
administration will in the end give it a recognized place. Let the number of schools where geography is taught increase just as rapidly as it can be taught and taught well. It is already popular in large schools; it ought also to extend to country schools. It can be taught without elaborate equipment in such schools where working material is ready at hand and where outdoor observations can be most easily made.

As the years go on and the need both of professional and technical training among teachers is made more manifest in the schools, this demand will extend with even greater force to the teaching of physical geography, and knowing something of the liberal manner in which the teaching ranks are recuperated each year we need not fear a dearth of teachers with the necessary equipment even in this comparatively new field.

The teacher of the next few years will still have great opportunities for original work and will at the same time have as a foundation for work the practical results of others' experience. He will find a stronger popular sentiment in favor of natural sciences and a greater willingness on the part of school authorities and among the pupils to work experimentally both out of doors and indoors, and the subject will all the time be a progressive one. An opportunity to watch development and to see actual results is a greater opportunity than that of taking a subject at its height and with only the possibility of keeping it up to that point or struggling against its decline. Without desiring that the work in physical geography shall be one of absolute uniformity, it will yet be an improvement in the future to maintain a greater uniformity of general principles, a more vigorous attack and a surer touch in treatment to emphasize the process of growth and change, to recognize the human side more fully, and to build up a system of classification which shall enable the student to grasp the subject more comprehensively and give to him a working standard with which to measure the world wide.

We look back upon a period of disintegration and decay, when old methods proved their futility and gave way before the new. We are in the midst of a period marked by experiment, by rapid growth and accomplishment. We look forward to a period of increased vitality, increased accomplishment, increased certainty. 